\title{
Teacher Quality and Student Academic Achievement in Basic Technology in Junior Secondary Schools in South-West, Nigeria
}

\author{
Joshua O. Oni, Ph.D. \\ Department of Educational Foundations and Management, \\ Olabisi Onabanjo University, Ago-Iwoye, Nigeria
}

\section{Doi:10.5901/jesr.2014.v4n3p397}

\section{Abstract}

The study examined the relationship between teacher quality and student academic achievement in Basic Technology in South-West, Nigeria. Descriptive survey and ex-post facto designs were used. Using stratified and simple random sampling techniques, five hundred and fifty-eight (558) principals and 558 teachers of Basic Technology from 558 schools were selected from 18 senatorial districts of Ekiti, Lagos, Ogun, Ondo, Osun, and Oyo States, the six states that make up South-West, Nigeria. A self-designed questionnaire and the results of the 2011/2012 Junior Secondary School Certificate Examination were used for data collection and analysis, respectively. The data collected were analysed using Pearson's Product-Moment Correlation Coefficient. Findings revealed, among others, that significant relationship existed between teacher quality and professional experience and student academic achievement. The implication of the findings for the government, policy makers and school principals were articulated.

Keywords: teacher quality, student academic achievement, Basic Technology

\section{Introduction and Overview}

Every serious nation the world over is very much interested in the issue of technological development. This is because success in technological growth is the springboard for social and economic development. This explains why technologyrelated courses are always central among mandatory subjects that students at the lower level of secondary education are required to pass for upward movement. (Levaic, 1995; Rijavec \& Brdar, 2002)

An important integral part of the Nigerian education system is junior secondary education. It is a programme of three years benefited by children whose ages range between thirteen (13) and fifteen (15) years. A core course in its curriculum is Basic Technology. The practice-oriented subject is included so as to develop practical and applied skills in the young ones. Teaching and learning of the subject are supposed to ensure inculcation of technological literacy, that is, basic understanding of and capability in technology; exposure of the beneficiaries to the world of work to match their talents and interests for wise vocational choice; and instillation of positive attitudes toward work as a source of human identity, livelihood and power.

Acquisition of knowledge in the subject is one of the means by which the nation hopes to attain the Millennium Development Goals (MDGs) by 2015 and the important targets of the National Economic Empowerment and Development Strategies (NEEDS). (Nigerian Educational Research and Development Council, 2007) In one word, Basic Technology is supposed to contribute to the achievement of the national education goals by providing the required technical knowledge and vocational skills.

The determination of world bodies to ensure literacy of citizens all over the globe has also served as impetus and a catalyst to efforts made by the Nigerian government. Education for all by 2015 and other targets of government have engendered signing of several projects and, by extension, doing all that she could in investing in education so as to facilitate the achievement of the nation's educational goals.

Admittedly, government has lofty goals, the performance of students in external examination, which is an important tool in measuring standard, has been poor. In the last few years, precisely between 2009 and 2011, the percentage of failure in national examinations, conducted by West African Examinations Council (WAEC) and National Examinations Council (NECO), respectively, has been rather high. The core science subjects, particularly mathematics and physics, are worst.

Results of the examinations conducted by NECO in May/June 2009 revealed that only 126,500 (i.e. 10.68\%) of the $1,184,907$ candidates that sat for the examinations passed with credit in five subjects including mathematics. In 2010, out 
of the $1,113,177$ candidates that sat for the examinations, only 285,146 (i.e. $25.62 \%$ ) passed with either distinction or credit in mathematics. 870,305 (i.e. $78 \%$ ) of the candidates failed to obtain credit pass in English language. Since obtaining credit pass in English and mathematics is a compulsory prerequisite condition for admission into any Nigerian university, the implication is that $78 \%$ of the total number that sat for the examinations that year would not be able to have access to university education. In 2011, out of the 1,190,511 candidates, 295,961 (or 24.86\%) passed mathematics at credit level and only 263,777 (i.e. 22.16\%) obtained credit level pass in English language. The core science- and technological-based subjects like physics and chemistry were not spared of the woeful performance, either. (Sunday Punch, October 9, 2011, p. 13)

Students' poor performance at the senior secondary level, as indicated in the last paragraph, points to one thing: everything was not well with the education received by the students at the junior secondary school, the level that is of interest to us. That they performed poorly in subjects like physics and mathematics could only mean that they had not been properly groomed in subject like Basic Technology at the JS 1, JS 2 and JS 3.

The ugly situation should be a source of concern to all stakeholders, both at home and abroad. This is because poor performance at secondary education, a level which is supposed to prepare students for higher education and useful living in the society, will have serious consequences amongst which are inability of the students to meet the requirements for admission into institutions of higher learning which, in turn, will have negative impact on social and economic development of the nation.

For years, educators and researchers have debated which school variables influence student academic achievement. As governments now seems to be more involved in school reforms, this question takes on new importance since her many initiatives rely on presumed relationships between various education-related factors and learning outcomes.

Some research outcomes, including those of Sonam (1994) and Adesola (2005), suggested that schools bring little influence to bear upon a child's achievement that is independent of his background and general social context. The findings of Ferguson (1992) and O'Neill (2001), among others, on the other hand, emphasized that teacher's qualification and other school variables may play an important role in what students learn. They affirmed that learning is a complex activity that involves interplay of teaching resources, skills of teaching, and the curriculum, among other things. Other scholars including Darling-Hammond (1999) and Obanya (2003) asserted that the quality of an educational system depends on the quality of the teachers. Ferguson (1992) and Wenglinsky (1992), in different studies, found that the single largest factor affecting academic growth of students is differences in effectiveness of individual classroom teachers.

Teachers have been recognized as indispensable human resource and, indeed, the single most important element in the school system, more important than the quality of equipment and materials and the level of financing. (U S Department of Health Education and Welfare, Office of Education, 1970) Teachers are very important. On account of the importance, the education law in Nigeria provides that: "No person shall teach in any school unless his name has been placed on the register of teachers or after his name has been removed from such register." (Education [Lagos] Ordinance 1962) The position has not changed, more than four decades later. As of now, one is legally recognized as a teacher if his name is in the register of the Teachers Registration Council and he ceases to be a teacher once his name is deleted from the register. (Teachers Registration Council, 2004)

According to Harris and Sass (2011), it is accepted in general that promoting teacher quality is a key element in improving primary and secondary education in the United States. In like manner, researchers, including Bajah (1979), Obanya (1982), Ajayi (1989), Hallak (1990), Hanushek and Rivkin (2006), have all found and emphasized that the quality of the education system depended on the quantity, quality and devotion of its teaching work force.

Okoye, Momoh, Aigbomian, \& Okecha (2008) conducted a study which examined the correlation between two independent variables of teacher quality and instructional strategy on students' performance in secondary school science in Ethiope East and Ukwuani Local Government Areas of Delta State. The result showed that the teacher quality and instructional strategy had positive significant relationship with achievement in science; and that teacher quality and instructional strategy were two non-separate interactive independent variables in science education.

In a study, entitled: "Teacher Quality Moderates the Genetic Effects on Early Reading," Taylor, Roehrig, Hensler, Connor and Schatschneider (2010) found that children's reading achievement was influenced by genetics as well as by family and school environments. They studied first- and second-grade students in Florida from schools representing diverse environments. Comparison of monozygotic and dizygotic twins, differentiating genetic similarities of $100 \%$ and $50 \%$, provided an estimate of genetic variance in reading achievement. Teacher quality was measured by how much reading gain the non-twin classmates achieved. The magnitude of genetic variance associated with twins' oral reading 
fluency increased as the quality of their teacher increased and that poor teaching impeded the ability of children to reach their potential.

Akinfe, Olofinniyi \& Fashiku (2012) conducted a study entitled: "Teachers' Quality as Correlates of Students Academic Performance in Biology in Senior Secondary Schools in Ondo State, Nigeria." They found that: the role of professionally qualified/trained teachers was an important teacher quality which enhanced students' academic achievement in biology; teaching methods adopted by the teachers significantly influenced achievement of the behavioral objectives; and that teachers' experience significantly influenced students' academic performance.

Research findings have also established that teacher's teaching experience is positively correlated with learning outcome. Raw (2003) affirmed that teachers with years of experience in the profession turned out students with higher academic performance. This is due to the fact that these teachers are able to harmonise the minds and emotions of their students in class and this produces better academic achievement.

So far, much efforts seem to have been directed at mathematics and English language, which are two key subjects and extremely important for those with the intent of advancing their education in any Nigerian university, and also at the sciences. There is dearth of effort, if any at all, towards determining the quality of teachers at the junior secondary level, particularly in subject like Basic Technology. The present study set out to fill this gap.

\subsection{Statement of the Problem}

Development is often equated with level of technology, industrialization and westernization. The acquisition and application of essential knowledge in Basic Technology are regarded as the very foundation of technological and industrial development of any nation. The problem of this study concerned establishing the degree of correlation, if any, between teacher quality and student academic achievement in Basic Technology.

Any activity directed toward ensuring quality in Basic Technology at the junior secondary education level is worthwhile. This is so as it will go a long way in determining student academic achievement in related subjects like physics and mathematics at external examinations conducted by NECO and WAEC whose outcome is used by many as a yardstick for measuring the entire secondary education in Nigeria. More importantly, investigating the strength of correlation between the independent and dependent variables is considered worthy now at a time that Nigeria envisions to be one of the twenty (20) largest economies in the world, able to strengthen its leadership role in the continent and establish itself as a major player in the global economic and political arena by 2020, i.e. a few years from now.

\subsection{Statement of the Hypotheses}

Ho1. There is no significant relationship between teacher quality and student academic achievement in Basic Technology.

Ho2. There is no significant relationship between teachers' experience and student academic achievement in Basic Technology.

\section{Methodology}

\subsection{Design}

The study employed the use of descriptive survey and ex-post facto research designs. This is due to the fact that the independent variable (teacher quality) being investigated has already occurred and the researcher is only interested in knowing its influence on the criterion variable (student academic achievement in Basic Technology) without necessarily manipulating the independent variable.

\subsection{Population of the Study}

This correlational study was carried out in South-West, Nigeria. This geo-political zone is made up of six states. These are: Ekiti, Lagos, Ogun, Ondo, Osun, and Oyo. The population comprised one thousand, five hundred and fifteen $(1,515)$ public junior secondary schools and junior secondary schools combined with senior secondary schools. The distribution is as follows: Ekiti State (126), Lagos State (360), Ogun State (252), Ondo State (281), Osun State (208) and Oyo State (288). Since Basic Technology was compulsory, all the public schools were supposed to be offering the subject. All the 
principals as well as the teachers of Basic Technology in all the public schools comprised the population.

\subsection{Sample and Sampling Procedure}

Stratified and simple random sampling techniques were used. The first stage of stratification was represented by three (3) Senatorial Districts of each of the six (6) states that constitute the South-West, Nigeria.

Ninety-three (93) public secondary schools, each of which has a minimum of one (1) Basic Technology teacher, were randomly selected from the total number of schools in each state. From each school, a principal (or vice principal) and one Basic Technology teacher were selected as sample. Altogether, ninety-three (93) principals (or vice principals) and ninety-three (93) teachers were selected per state; and five hundred and fifty-eight (558) principals (or vice principals) and five hundred and fifty-eight (558) teachers of Basic Technology from the geo-political zone. This number was considered appropriate because since all the schools from which the sample was drawn were run by one agency, some homogeneity was assumed. The ages of the sample ranged between 26 and 53 years; their mean age was 35.4 years with a standard deviation of 3.3.

\subsection{Instrument}

A self-designed questionnaire, entitled: 'Basic Technology Resource Description and Schools' Academic Performance Questionnaire'-Forms I and II for principals and teachers (who taught Basic Technology in 2011/2012 academic session), respectively, was employed for data collection. The twenty items focused on teacher quality and professional experience. The cronbach's alpha of the questionnaire was 0.62. The results of the 2011/2012 Junior Secondary School Certificate Examination were used to determine the student academic performance in Basic Technology.

\subsection{Procedure and Data Analysis}

The researcher personally administered the questionnaire in Obafemi-Owode, a Local Government Area that was used as pilot study. He employed the help of six (6) research assistants in administering the questionnaires to respondents in each of the six (6) states. A total of four weeks and four days were used for the administration and collection of the questionnaires. All the questionnaires administered were retrieved. However, only questionnaires from five hundred and fifty-six (556) schools were properly filled and deemed adequate for analysis. The response rate of the survey was $99.6 \%$.

The data resulting from the scoring of the instrument and coding of the demographic items were then subjected to Pearson's Product-Moment Correlation Co-efficient statistical analysis.

\section{Results}

The results of the study are presented in the tables below.

Ho1. There is no significant relationship between teacher quality and student academic achievement in Basic Technology.

Table 1: Relationship Between Teacher Quality and Student Academic Achievement in Basic Technology

\begin{tabular}{|l|c|c|c|c|c|l|}
\hline & $\mathrm{N}$ & $\mathrm{X}$ & $\mathrm{SD}$ & $\mathrm{R}$ & $\mathrm{S}$ Sig & \multicolumn{1}{c|}{ Remarks } \\
\cline { 1 - 6 } Teacher Quality & 556 & 2.829 & 0.955 & \multirow{2}{*}{$.105^{\star}$} & \multirow{2}{*}{.013} & \multirow{2}{*}{$<.05$} \\
\hline Academic Achievement & 556 & 1.715 & 0.362 & & \\
\hline
\end{tabular}

* Correlation is significant at the 0.05 level (2-tailed)

The table above shows that there is significant relationship between teacher quality and student academic achievement in Basic Technology $(r=0.105 ; p<0.05)$. This implies that the null hypothesis, which stated that there is no significant relationship between teacher quality and student academic achievement in Basic Technology was rejected. It, therefore, means that teacher quality would influence student academic achievement in Basic Technology.

Ho2. There is no significant relationship between teachers' experience and student academic achievement in Basic Technology. 
Table 2: Relationship Between Teachers' Experience and Student Academic Achievement in Basic Technology

\begin{tabular}{|c|c|c|c|c|c|c|}
\hline & $\mathrm{N}$ & $X$ & SD & $\mathrm{R}$ & Sig & Remarks \\
\hline Teachers' Experience & 556 & 2.721 & 0.863 & \multirow{2}{*}{$.101^{*}$} & \multirow{2}{*}{.017} & \\
\hline Academic Achievement & 556 & 1.715 & 0.362 & & & \\
\hline
\end{tabular}

The table above shows that there is significant relationship between teachers' experience and student academic achievement in Basic Technology $(r=0.101 ; p<0.05)$. This implies that the null hypothesis, which stated that there is no significant relationship between teachers' experience and student academic achievement in Basic Technology, was rejected. It, therefore, means that teachers.' professional experience would influence student academic achievement in Basic Technology.

\section{Discussion}

The study sought to investigate the relationship between teacher quality and student academic achievement in SouthWest, Nigeria. This research theme is hinged on the need to provide an empirical basis for the improvement of the student achievement in technology-related subject. The results showed that relationship existed between teacher quality and experience and student academic achievement in Basic Technology.

This finding is consistent with the available literature. Obanya (2003) and Adesola (2005), for instance, established that the role of professionally qualified/trained teachers is an important teacher-quality which enhances student academic achievement. In a similar study, Darling-Hammond (1999) established that the single largest factor affecting academic growth of the population of students is differences in effectiveness of individual classroom teachers. In the same vein, O'Neill (2002) established that good teacher have distinguished impact on students' academic performance. These findings underscore the fact that it is the teachers that have the quantifiable ability to produce growth in students' achievement; and the quality of any teaching-learning situation depends, to a great extent, on the quality of the teachers.

The implication of this is that the teaching of Basic Technology, which is an important subject, requires planning and systematic delivery of instruction in such a way that the stated objectives can be achieved. The teaching should not be done by just any teacher who is not certificated in the subject. It should be noted that if unqualified teachers are allowed to teach the subject, they may impart wrong information which may lead to misinformation and, worse still, may make the students become dangerous for the society to cope with at a later time in future.

Also, the findings revealed that relationship existed between teachers' experience and school's academic achievement in Basic Technology. These findings are not unexpected considering the findings of previous studies on similar subjects with practical orientations such as biology, chemistry, etc. As an example, Akinfe, Olofiniyi and Fashiku (2012) established that teachers' experience contributes maximally to student academic performance. According to them, teachers with cognate teaching experience turn out students with relatively higher academic achievement. Raw (2003) had also established that teacher's teaching experience influenced students learning outcome. According to him, these teachers are able to harmonsie the minds and emotions of their students in class and this produces better academic achievement.

\section{Conclusion}

From the foregoing, it is clear that teacher quality, in terms of qualification, exposure to seminars and conferences and on-the job training as well as years of experience in service are factors that matter in student academic achievement in Basic Technology. Since it is not possible for one to give what he does not have, unqualified and inexperienced teachers are not likely to deliver to the expectation of the curriculum in the classroom. Government and policy makers should, therefore, ensure that junior secondary schools across the nation and particularly, South West, Nigeria, are provided with sufficient and adequate number of teachers that can successfully handle the teaching of Basic Technology to the satisfaction of the students. The present practice in most schools where subjects were allocated to teachers by the principals on the basis of availability and at the detriment of qualification should be revisited with a view to putting round peg in round hole. 


\section{References}

Adesola, A. A. (2005). Resources provision and utilization, mathematics ability and learning environment as predictors of learning outcomes in undergraduate practical geography. Unpublished Doctoral Thesis, University of Ibadan, Ibadan.

Ajayi, K. (1989). Educational development and management in Nigeria since independence. Ibadan: Vantage Publication Ltd.

Akinfe, E., Olofinniyi, O. E., and Fashiku, C. O. (2012). "Teachers' Quality as Correlates of Students' Academic Performance in Biology in Senior Secondary Schools in Ondo State, Nigeria." Online journal of education research. Volume 1, Issue 6.

Bajah, S. T. (1979). "Correlates of Students Extrinsic School Environment Factors With Level of Attainment in a Standardized Test in Chemistry." Journal of the science teachers' association of Nigeria (STAN), Vol. 18, No. 1.

Darling-Hammond, L. (1999). Teacher Quality and Student Achievement: A Review of State Policy Evidence. University of Washington: Centre for Study of Teaching and Policy.

Education [Lagos] ordinance 1957 with subsequent legislation. (1962). Lagos: Government Printer.

Ferguson, T. S. (1992). The theory of science inquiry. New York: Allen Publications.

Hallak, J. (1990). Investing in the future: setting educational priorities in the developing world. Paris: UNESCO-IIEP.

Hanushek, E. A. \& Rivkin, S. G. (2006). "Teacher Quality." In Hanushek, E. \& Welch, F. (2006). (Eds.). Handbook of the Economics of Education. Edition 1, Volume 2, Number 2. Elsevier: Netherlands.

Harris, D. N. \& Sass T. R. (2011). "Teacher Training, Teacher Quality and Student Achievement." Journal of public economics. 95 (7).

Levaic, R. (1995). "Linking Resources to Learning Outcomes." In Coleman, M. \& Anderson, L. (1995). (Eds.). Managing financial education. London: Slege Publication.

Nigerian Educational Research and Development Council. (2007). Federal Ministry of Education 9-Year Basic Education Curriculum: Basic Technology for Junior Secondary $1-3$. Abuja: Author.

Obanya, P. A. I. (2003). "Quality Education of Basic Education: A Comparative Model." Nigerian journal of educational research and evaluation. 1 (4). $87-89$.

Obanya, P. A. I. (1982). Teaching and cheating. An Inaugural Lecture Delivered at the University of Ibadan.

Okoye, N. S., Momoh, S. O., Aigbomian, D. O. \& Okecha, R. E. (2008). "Teachers' Quality, Instructional Strategies and Students Performance in Secondary School Science." Journal of instructional psychology. Volume: 35 Source Issue: 2

O'Neill, G. (2001). Designing coherent education policy: improving the system. San Francisco: Jossey-Bass.

Raw, V. K. (2003). Quality teaching. Dew Delhi: APH Publishing Company.

Rijavec, M. \& Brdar, I. (2002). "Coping With School Failure and Self-regulated Learning." European journal of psychology of education. xvii, 2. 177-193.

Sonam, W. (1994). "The Relationship Between Bhutanese Students' Achievement in Science, School Resources, Teacher Qualifications and Performance in English." UMB/Bhutau Project. Retrieved from www.uhbf.caleducation/Bhutauproject/sonam.htm.on 15th December, 2012.

Taylor, J., Roehrig, A. D., Hensler, B., Connor, C. M. \& Schatschneider, C. (2010). "Teacher Quality Modersates the Genetic Effects on Early Reading." Science magazine. Volume 328, Number 5977.

Sunday Punch. (2011, October 9). "Arbitrary Trend of Mass Failure in NECO Examinations."

Teachers Registration Council. (2004). Teachers Code of Conduct.

U S Department of Health Education and Welfare, Office of Education. (1970). Do teachers make a difference? (Report of a Conference Sponsored by the Publishers.

Washington, D.C.: U.S. Office of Education.

Wenglinsky, T. K. (1992). Biological science. New York: Columbia University Press. 